\title{
With words I cannot say: giving new meaning to care through music in cardio pediatric postoperative
}

\author{
Com palavras não sei dizer: ressignificando o cuidado através da música em pós-operatório \\ cardiopediátrico
}

Odemir Pires Cardoso Júnior ${ }^{1}$, Mara Marusia Martins Sampaio Campos², Mônica Cordeiro Ximenes de Oliveira², Maria Tereza Aguiar Pessoa Morano ${ }^{3}$, Maria Valdeleda Uchoa Morais Araújo ${ }^{2}$, Kellen Yamille dos Santos Chaves ${ }^{4}$

Objective: to understand the new meanings that music promotes in the care of children in cardio pediatric surgery postoperative. Methods: qualitative research with professionals of the multi professional health team through a semi-structured interview based on the Content Analysis method. Results: professionals perceived the Pediatric Intensive Care Unit as a scenario susceptible to deterioration in the quality of care. In addition, they considered that the use of music, as an integrative and complementary therapy, fostered the production of senses in health care, proving it capable of providing relaxation, distraction, well-being, pleasant memories and comfort to professionals and hospitalized children. Conclusion: music contributed to give new meaning to care optimizing humanization and restructuring health promotion processes. The experience provided reflections, skills, emotional expression, sensations and feelings such as relaxation, distraction and well-being in the multi professional team. Child care has been expanded, combining the technological arsenal with concern for comfort and emotional state.

Descriptors: Intensive Care Unit, Pediatric; Heart Diseases; Thoracic Surgery. Music.

Objetivo: compreender as ressignificações que a música promove no cuidado às crianças em pós-operatório cardíaco. Métodos: pesquisa qualitativa com profissionais da equipe multiprofissional de saúde por meio de entrevista semiestruturada baseada no método de Análise de Conteúdo. Resultados: os profissionais perceberam a Unidade de Terapia Intensiva Pediátrica como cenário suscetível de deterioração na qualidade da assistência. Ademais, consideraram que o uso da música, como terapêutica integrativa e complementar, fomentou a produção de sentidos na atenção à saúde, mostrando-se capaz de proporcionar relaxamento, distração, bem-estar, recordações agradáveis e conforto aos profissionais e às crianças internadas. Conclusão: a música contribuiu para a ressignificação do cuidado otimizando a humanização e reestruturando os processos de promoção de saúde. A experiência proporcionou reflexões, habilidades, expressão emocional, sensações e sentimentos como relaxamento, distração e bem-estar na equipe multiprofissional. 0 cuidado à criança foi ampliado, aliando o arsenal tecnológico à preocupação com o conforto e estado emocional.

Descritores: Unidades de Terapia Intensiva Pediátrica; Cardiopatias; Cirurgia Torácica; Música.

\footnotetext{
${ }^{1}$ Faculdade Maurício de Nassau. Natal, RN, Brazil.

${ }^{2}$ Centro Universitário Christus. Fortaleza, CE, Brazil.

${ }^{3}$ Universidade de Fortaleza. Fortaleza, CE, Brazil.

${ }^{4}$ Maternidade Escola Assis Chateaubriand. Fortaleza, CE, Brazil. 


\section{Introduction}

The human being, when experiencing a process of illness, can perceive reality in a different and unique way. Several important structural and emotional changes involving sensations, feelings, pains and uncertainties come to integrate their existence, as well as new relationships and interrelations, implying, directly or indirectly, improvement in their quality of life. Thus, any disease process experienced in childhood that dispenses long periods of treatment, frequent medical returns or even recurrent hospitalizations, can generate serious complications in the development of children ${ }^{(1)}$.

Congenital heart diseases, included among the chronic organic pathologies defined as cardiac malformations that occur in the embryonic period, represent real or potential functional severity. Therefore, due to the complexity of the disease, the diagnostic characterization and the indication for surgical correction are relevant ${ }^{(2)}$. In this context, postoperative management of these patients requires follow-up in a Pediatric Intensive Care Unit with the use of invasive mechanical ventilation in the immediate postoperative period.

By apprehending the impact of hospitalization for the child, vital measures for improving child health are essential. Thus, in the last five years, music in hospitals has been consolidating its presence, due to the Humanization Program of Hospital Assistance proposed by the Secretary of Health, which can be understood as one of the integrative and complementary therapeutic strategies directed to care through of the personification of the hospital areas ${ }^{(3-4)}$.

Music, for centuries, has been used as a therapeutic form, and there are numerous examples of its curative and preventive powers in various historical documents of different cultures. The use of this strategy in hospitals portrays the addition of non-pharmacological agents as care explorers, as well as the term music therapy, a theme used as a scientific basis in this study, whose intention is the elaboration of a music-based care plan to meet physical, social and psycho- logical needs of the patients ${ }^{(4-5)}$.

This possibility of expression and communication that characterizes the musicality can collaborate to give new meaning to the period of hospitalization so that the patients feel welcome and considered regarding their dimensions of identity and subjectivity. Music therapy can contribute to the hospital environment becoming more relaxed and pleasant insofar as it acts directly on the feelings of the participants, seeking to alleviate tensions and provide moments of positive social exchanges ${ }^{(6)}$.

Studies of this nature are considered important, since they seek to understand subjective questions in the processes of work organization that has musical therapy as a tool. The initiative to provide a valuable and differentiated tool in the search for more humanization and interdisciplinarity of care is relevant to broaden the scope of actions in children's health. Thus, with the help of music, the hospitalization environment and the interventions become moments that refer only to the experience, not the suffering.

The aim of this study was to understand the significations that music promotes in the care of children in cardiac surgery.

\section{Methods}

This is a qualitative research. The research area was the Pediatric Cardiology Intensive Care Unit of a reference hospital in the treatment of cardiopulmonary diseases in the city of Fortaleza, CE, Brazil, from March to April 2015.

The population consisted of professionals of the health team, of both sexes, who served in the pediatric intensive care unit with a minimum of six months of time and who followed the routine of the child in the unit. Those professionals whose work dynamics (shifts) did not allow a daily contact with hospitalized children, as well as those who did not agree to participate in the research, were excluded from the study.

The sample consisted of ten professionals, two physiotherapists, two nurses, three nursing assis- 
tants, two nursing technicians and one physician. Diversity was used as the selection criterion, choosing professionals who considered the various categories and saturation of information to close the final size of the informant sample ${ }^{(7)}$.

Participants were approached individually and informally and clarified about the study. Data collection took place in two moments. In the first one, the musical intervention in the scenario (lullabies, classical music and sounds of the uterine environment) was carried out for 14 uninterrupted days in intercalated shifts. During that time, 60 minutes, the researcher observed the team during performing some procedures, as well as their actions and reactions with the musical intervention that were described in a field diary.

In the second moment, interviews were conducted during office hours, Monday through Friday, with the following guiding question: "How can professionals give new meaning to care through music?" In addition, topics such as the routine and the conduct of each professional, the musical intervention and the changes provoked in the child were approached, which enabled the interviewee to speak freely about the proposed subject. The interviews were recorded and reliably transcribed.

The data were analyzed through the Content Analysis method, which proposes to find answers to the formulated questions as well as to discover the elements that are inherent to the manifest content $t^{(8)}$. In the diaries of fields or speeches, pseudonyms related to the types of musical instruments: keyboard, flute, guitar, guitar, drums, viola and trumpet were used as well as children's songs (Pirulito que bate, bate; Ciranda Cirandinha; Atirei o Pau no Gato, Marcha Soldado; Escravos de Jó) to safeguard the anonymity of the children and the multi professional team involved in the research.

The analysis of the data occurred through exhaustive floating reading. The following categories of analysis emerged: The dynamics of a Pediatric Intensive Care Unit, it seems that time does not stop and there will always be a voice taking care with music.
The study respected the formal requirements established by national and international regulatory standards for research involving human subjects.

\section{Results}

In the first category of analysis, it is sought to know how healthcare professionals perceived the environment of the Pediatric Intensive Care Unit.

\section{The dynamics of a Pediatric Intensive Care Unit: it seems that time does not stop}

Reflecting on the hospital scenario and a Pediatric Intensive Care Unit, at first it can lead to the conclusion that these privileged spaces, silent, with the most sophisticated equipment, count on a multidisciplinary team experienced in the care of the child. However, the sector studied was perceived by the multi professional team as one of the most aggressive, fearful, tense and traumatizing environments of the hospital. When the baby arrives in the lap of the mother and is delivered inside the Intensive Care Unit, this scene is remarkable, you will never forget, because it is such a great pain, you see the tears in her eyes, because the baby as soon as it has just been born, she does not even have the pleasure of putting him on her lap and taking him home, he has to come from the other hospital here; so it all hurts inside us as a professional; you imagine yourself in her place (Pirulito que bate, bate - Two). It seems that time does not stop ... an environment in which handling is more frequent, in which procedures are more common, so there is greater brightness, a little louder noise, even children, it is not, they are more active, already speak, already cry, then all this influence (Ciranda cirandinha - One).

On this issue, there are important signs and symptoms in this scenario, which may deteriorate the quality of care, such as the somatization of emotional distress, the feeling of professional impotence, followed by the lack of preparation to deal with the family in the presence of deaths. Thus, it is opportune to rethink the production of health care in this context. As I enter the room, in the morning, I feel the scenario tense. Keyboard (child) is already prepared for surgery, that is, the entire checklist of 
procedures has already been made, highlighting the fast from eight to twelve hours; however, the child's poor prognosis seems to reflect significantly among the professionals: apprehensive looks, hangover looks and silences. At 10:30 a.m., the statement is received that there will be no further surgery. The Staff expresses their sense of fear, fearing that she will not resist it if she is listed again (Field Diary - Day Three).

In the field observation, it was noticed that the labor dynamics itself did not allow moments of reflection among the professionals about the singularity of their performance, therefore, it is up to each one to use strategies that make humanization viable to the detriment of the mechanical and biological view that in high technology centers, as in the case of intensive therapy units. ... But my greater care, besides hygiene, to use when I get close to him, put on the cap, put the mask on the most infected patients, put on the glove, I try to talk to the patient; I try to pay attention to the baby, not to be just a patient; Ah, it's just a single ventricle that's there; it's just a Blalock post-operative; no, for me it's a patient $x$, it's the Flute, it's the Guitar, it's the Guitar (children), you understand? (Escravos de Jó). ... with every touch you get in them, they like it, right? Since there is no mother around (Atirei o pau no gato - Two).

The systematic observations, recorded in the field diary, show that the multi professional team needs to know how to respond positively to the automation of hospital care, humanizing care based on the impact of these actions. In the morning, usually, the medical visit begins to the bed. Clinical, prognostic and referral charts are discussed for all children hospitalized at that unit. It lasts about an hour. No non-medical professional is present at the moment (Field diary - Day seven). What should change ... the companionship among colleagues who, most of the time, there is not; but it's not here, everywhere it's like this (Atirei o pau no gato - One).

It was observed that there is some accommodation in the routine and the wear caused by the work in an intensive care unit, mainly in situations of stress, work overload or urgency, altering the good performance of the professionals in the procedures, in the interventions and their relation with the drink. In spite of detecting its vital importance, the number of activities, such as tube feeding, hygiene, medication administration, collection of exams, exchange of dressings and endotracheal aspiration, constitute for a long time as negative stimulations, resulting in consequences for care, as mentioned in the interviews below. Depending on the way you touch the child, it reacts in a way. Necessarily, not every day we have the energy, so, you can say, very good, is not it? So, there are days when we're a little ruder about how to pick up the child, right? And there are moments when you are more delicate ... this also varies a lot on the day; ends up somehow causing our mechanics to change a little (Ciranda cirandinha - Two). It is to catch with the cold hand, I, I, what I do with him, understood? What bothers most is when I play with the icy hand (Escravos de Jó).

The report emphasizes that in this environment of urgency and immediacy so dominated by specialization, the team is often directed to the domain and manipulation of technologies. Therefore, it is observed that many activities in an intensive care situation seem to occur even between the team and the machines, subjects and objects. I think, therefore, that the ideal environment, I think it should have all the support that the child needs, because the unit of intensive therapy itself, the name itself says, is of serious patients; needs all the necessary support the child needs (Marcha Soldado). The morning at the intensive care center always gets busy. The atmosphere is taken by the symphony of mechanical fans, infusion pumps combined with children's crying. Every professional performs his or her job. No one questions the importance of the existence of technology. One observes, yes, the mastery in its manipulation (Field Diary - Day nine).

Equipment noise, such as monitors, respirators, and infusion pumps, is needed because, when they alarm, they often mean problems. However, they are also harmful to health professionals, and there is a need to review postures, emphasizing the convenience of adjusting the alarms of the equipment in order to prevent unnecessary noise, as observed in the speeches of the professionals below... Minimal alarm possible, this does not mean that it is not present, of course, but it is, in my opinion, like this: we have to check the reason for the alarm and, that is, try to do whatever it takes to be able to heal. This is not to say that it is just to get there and turn off the alarm, without checking if it is a false alarm, whether it is the patient himself who is decompensating or not (Escravos de Jó). ... the Intensive Care Unit, it is very noisy, because of the monitors that are directly alarmed, because you cannot put, is, 
suspend these alarms because the children are in serious condition and, at a moment's notice, the that happens if you have suspended the alarm, you may well not detect at the ideal time, then there is the whistle, there is the noise of the monitors, right ... (Pirulito que bate, bate - Two).

The second category of analysis contemplated the perception of the professionals of the Intensive Care Unit about the strengthening of the caring dimension through music.

\section{There will always be a voice: taking care with music}

The evolution of technology in intensive care units has modified the prognosis and survival of high-risk children. However, the incidence of patients with decreasing levels of consciousness increased, and, above all, the impact on the care of critically ill patients decreased. ... That even sedated children, they listen, they feel ... there is always going to be a voice, then we need to decrease people talking too loud ... an education more directed to respect the moment of the child who is to be rehabilitated (Pirulito que bate, bate-One).

The impact that features such as the endotracheal tubes used in mechanical ventilation, commonly found in patients undergoing cardiac surgery, interfere with the verbalization, compromising the interpersonal relationship is notorious. Thus, most patients still do not have verbal language developed and, therefore, crying, laughter and babbling serve as a means of social contact and diffuse communication with other people. The experiences and experiences with music, from the beginning of the field work of this research, responded that "the emission of sound" in the context of the Center of Intensive Therapy facilitates the opening of the communication channel, validating it as emotional language. Tromba (child) is in bed and starts to cry. She remains crying for about five minutes, intercalating moments of tonic and physiological disorganization, for a few moments. Nurse approaches, puts her on her lap and quickly backs her to the music. Child stops crying, accompanies the rhythm of music with his mouth and hands, when he then falls asleep (Field Diary - Day five).
Music can be used as a beneficial complementary therapy in the re-signification of care and its inclusion in the hospital context may be highlighted. The songs were very good, they calmed down more, the stress leaves you, you even forget that you are in a hospital environment (Atirei o pau no gato - Two).... even had, during the visit, and even so, since it's not the thing you usually see, relatives like that, I see it, so they stay like that, wow, like this: I think admiring, right? I think they even look very good. Situation of peacefulness, of joy (Marcha soldado - One).

Thus, interventions with music had important effects on the multi professional team, since it provided the capacity to stimulate abilities favoring emotional expression and stimulating the thinking and the reflection in the face of everyday situations. Drums (child) is tearful and does not even foresee what will happen. The placement of a central peripheral insertion catheter as an invasive procedure requires professional attention and skill. Musicality welcomes the moment. After a certain time, the feeling of happiness, through the conquest of the procedure, is visualized in the first attempt, associated to the professional's speech: "Today we started well" (Field Diary - Day eight). ... it's like that, if you're going to talk a little bit louder, you automatically get this way, right? Wow! I've said too loud, because the music is there relaxing so much that environment, that if you speak a little louder, make a little more noise, you even bother yourself (Marcha Soldado - Two).

It was observed that the use of musicality in the Treatment and Intensive Care Center contributed to the reintegration of the professional with the environment. The Intensive Care Unit nurse enters the unit minutes after using the music. Several facial expressions of pleasure are observed in this professional, highlighting his look, the beautiful smile and the cradling. The caller questions the specialist's posture. Her way of speaking draws attention, responding, feeling the music, rescuing her ballet times, emphasizing moments of a good past (Field Diary - Day four). While performing the care procedures with Viola (child), the nursing assistant focuses on where she is emitting the sound of the song and becomes emotional, reporting the positive experience of the music at the time of gestation. The intensity of affection in the handling of the child is perceived. He then goes to the nurse who is pregnant, and encourages her to lean her belly lightly, close to the sound (Field Diary - Day six).

The use of music in a hospital unit is not ex- 
clusive to the music therapist, since it can also be used to improve general and/or specific aspects of the individual's health, especially in the hospitalized patient. After explaining the team's intention to play music, the researcher starts the therapy. Suspicious looks, smiles, vocalizations surround the environment. Then, Staff and neonatologists leave the home, exchange looks and express reactions of astonishment, referring to never having seen music in pediatric environments, only in neonatology. Nurse complements, adding the existence of ambient music also in the hospital's parlor room. An informal conversation begins, emphasizing that this intervention is an innovative idea for the environment (Field Diary - Day One).

The musical experience in the hospital environment provoked feelings of motivation and inspiration, provided relaxation, distraction and comfort of the health team, enhancing care from the perspective of the expanded clinic. Interviews confirm that feelings promote organic manifestations and that the heart is the symbol of emotions, so it is important to highlight and foster the famous worldwide phrase of the book The Little Prince: "You can only see well with your heart, for the essential is invisible to the eyes ".... So we're always trying to ease that suffering, holding on to the little hand, right? Places a dummy, wraps, tidying up the child (Marcha Soldado - One). ... musical therapy, right? That I think is excellent, that for me, it is approved, that I like too much, I see great results even, of tranquility, of harmony, of serenity, of relaxation, both for people as professional, for the environment, as even for the children (Atirei o pau no gato Three).

In view of the experience, the importance of music in giving a new meaning to the actions practiced by the life-saving team is reiterated, once it is possible to see the humanization of care through it, characterizing itself as a valuable resource in child care in post cardiac surgery. Thus, the action of music in human beings and society is indisputable, as seen in the phrases of Tom Jobim's music: "I will tell you, the eyes can no longer see, things that only the heart can understand, love is fundamental, it is impossible to be happy alone".

\section{Discussion}

In order to understand the care of children undergoing coronary heart surgery, we take as a starting point the immersion of non-pharmacological agents in the labor universe, emphasizing that musicality has crossed barriers that have never been observed. However, the inference limitation of the research is evidenced due to the exposure time and the specificity of the theme associated to the need for new discussions about musical potentiality so that its breadth, dimension and relevance can be revealed at the core of the multi professional team.

The testimonies of the multi professional team suggest the loss of the caring dimension in health production, insofar as one can observe the mismatch between training and daily work. This study reveals that the concept of giving new meaning appears in the hospital context to feed and sensitize professionals, representing a practice of liberation and change against a decontextualized and vertical school ideology. Like this the pressing challenge is to perceive state-of-the-art technology, characterized by the cold and hostile environment, in the interface of caring and educating as a way of possibilities for (re) construction and (re) professional configuration ${ }^{(9)}$.

The experience reinforces that the inability to communicate in childhood through incipient verbal language in the perspective of pain does not equate to its absence, thus enhancing reflections on the impact caused by current health practices, guaranteeing them a better alternative or, if necessary, his improvement. The role of the professional being in relation to the care given to the need to redefine life, in the expression of creativity in the promotion of the singularity of the subject in human care is thus theorized ${ }^{(10-11)}$.

In order to broaden the discussion of the results, it is assumed that the expression form of the rational mind is the word, and that of the emotions is 
the non-verbal act. Therefore, the importance and the implications of investing in the institutionalization of the educator role in the team regarding the interpretation of non-verbal channels ${ }^{(12)}$, such as tone of voice, gestures, facial expressions, inferring meaningful learning (which promotes and produces senses) and reinventing the daily life of health services.

The data corroborate a study on the theme, which confirms music as a universal art form, revalidating its fundamental role of placing the patient in direct contact with their emotions, the sensations they bring and the situations in which they arise. Thus, the non-verbal expression through music may allow the health team to empty of anxieties, pains and feelings, exhausting their apprehensions about illness, life and death, fostering perspectives of a transforming $\operatorname{praxis}^{(13)}$.

Recent research highlights that teamwork and non-verbal communication are paramount in the practice of caring for children hospitalized at the Treatment and Intensive Care Center ${ }^{(14)}$. It is important to highlight the relevance of bringing music to work environments, as an interaction/integration tool, so that one can relate them to one another ${ }^{(6)}$. The sound universe, as a living process, adds values and enhances interpersonal relationships, which are the foundation of the reception, with non-verbal communication as the essence for humanized care in child care.

This study indicates the predominance of three technologies involved in health work, being: hard (represented by material as equipment, furniture), light-hard (includes the knowledge structured in the disciplines that work in the health area: dentistry, medical clinic, epidemiology, among others) and light (inserts the process of production of communication, relations, among others) ${ }^{(15)}$. In a context in which there is a predominance and necessity of using hard technologies, as the findings point out, the term "musical visit", as a therapeutic possibility, characterized in the musical intervention in the scenario studied, can be conceived as light technology, since it influences the team's implications and stimulates the expression of subjectivity, reinserting broad care as a core of professional action.

According to the interviews, it was evidenced that music, as a complement of care, alleviates suffering and integrates children into a place that for them is insecure and unknown, as well as captive, involves and moves from small to mature age ${ }^{(4)}$. At the moment, one could use the phrase "With words I cannot say", to express the non-verbal language of children that must be interpreted, understood, respected and welcomed by the whole multi professional team. In this sense, musicality, as energy, mobilizes, motivates and empowers this team, favoring the consolidation of renewed efforts and increasing the value of care, so that it can contribute to quality of life at work.

\section{Conclusion}

Music contributed to giving new meaning to care optimizing the humanization and restructuring the processes of health promotion. The experience provided reflections, skills, emotional expression, sensations and feelings such as relaxation, distraction and well-being in the multi professional team. Child care has been expanded, combining the technological arsenal with concern for comfort and emotional state.

\section{Collaborations}

Cardoso Júnior OP contributed in the conception and design, analysis and interpretation of the data. Campos MMMS, Oliveira MCX, Morano MTAP, Araújo MVUM and Chaves KYS contributed in the writing of the article and critical review of the intellectual content and final approval of the version to be published. 


\section{References}

1. Wottrich SH, Quintana AM, Camargo VP, Beck CLC. "Manifestations of the heart": meanings attributed to the disease by pre-surgical cardiac patients. Psicol Teoria Pesq. 2015; 31(2):2139.doi:http://dx.doi.org/10.1590/010237722015021127213219

2. Oliveira PMN, Held PAD, Grande RAA, Ribeiro MAGO, Bobbio TG, Schivinski CIS. Profile of children undergoing congenital heart surgery and analysis of their respiratory complications. Rev Paul Pediatr. 2012; 30(1):116-21. doi: http://dx.doi. org/10.1590/S0103-05822012000100017.

3. Barbosa GC, Meneguim S, Lima SAM, Moreno V. Política Nacional de Humanização e formação dos profissionais de saúde: revisão integrativa. Rev Bras Enferm. 2013;66(1):123-7.doi:http://dx.doi. org/10.1590/S0034-71672013000100019

4. Araújo TC, Alvaro P, Araújo MSS. Uso da música nos diversos cenários do cuidado: revisão integrativa. Rev Baiana Enferm [Internet]. 2014 [citado 2017 jul 13]; 28(1):96-106. Disponível em: https:// portalseer.ufba.br/index.php/enfermagem/ article/view/6967/8712

5. Gattino GS, Silva LCD, Moura A. Musicoterapia e educação musical no contexto hospitalar: aproximações e distanciamentos. Rev InCantare [Internet]. 2016 [citado 2017 jul 13]; 7(1):75-85. Disponível em: http://periodicos.unespar.edu.br/ index.php/incantare/article/view/822

6. Araújo TC, Silva LWS. Music: a care strategy for patients in intensive care unit. Rev Enferm UFPE on line [Internet]. 2013 [cited 2017 Jul 13]; 7(5):1319-25. Available from: http://www. revista.ufpe.br/revistaenfermagem/index.php/ revista/article/viewArticle/3167

7. Fontanella BJB, Magdaleno Júnior R. Theoretical saturationin qualitative research:psychoanalytical contributions. Psicol Estud. 2012; 17(1):6371.doi:http://dx.doi.org/10.1590/S141373722012000100008

8. Cavalcante RB, Calixto P, Pinheiro MMK. Analise de Conteúdo: considerações gerais, relações com a pergunta de pesquisa, possibilidades e limitações do método. Inform Soc [Internet]. 2014 [citado 2017 jul 13]]; 24(1):13-8. Disponível em: http:// www.ies.ufpb.br/ojs/index.php/ies/article/ view/10000/10871
9. Flores GE, Oliveira DLLD, Zocche DAD. Permanent education in the hospital context: the experience that brings new meaning to nursing care. Trab Educ Saúde. 2016; 14(2):487-504. doi: http:// dx.doi.org/10.1590/1981-7746-sip00118

10. Melo HCD, Araújo SEGD, Veríssimo AVR, Santos VEFAD, Alves ERP, Souza MHND. The nurse-being dealing with the care to the child in the immediate post-operative cardiac surgery. Esc Anna Nery. 2012; 16(3):473-479. doi: http://dx.doi. org/10.1590/S1414-81452012000300007.

11. Silva RCD, Ferreira MDA. The practice of intensive care nursing: alliance among technique, technology and humanization. Rev Esc Enferm USP. 2013; 47(6):1325-32. doi: http://dx.doi. org/10.1590/S0080-623420130000600011

12. Pontes EP, Couto DL, Lara HDMS, Santana JCB. Nonverbal communication in the pediatric intensive care unit: perception of the multidisciplinary team. Rev Min Enferm. 2014; 18(1):152-63. doi: http:// dx.doi.org/10.5935/1415-2762.20140012

13. Silva Júnior JDD. Música e saúde: a humanização hospitalar como objetivo da educação musical. Rev ABEM [Internet]. 2012 [citado 2017 jul 13]; 20(29):171-83. Disponível em: http:// www.abemeducacaomusical.com.br/revistas/ revistaabem/index.php/revistaabem/article/ view/99

14. Evangelista VC, Domingos TDS, Siqueira FPC, Braga EM. Multidisciplinary team of intensive therapy: humanization and fragmentation of the work process. Rev Bras Enferm 2016; 69(6):1099107. doi: http://dx.doi.org/10.1590/0034-71672016-0221

15. Nietsche EA, Lima MGRD, Rodrigues MDGS, Teixeira JA, Oliveira BNBD, Motta CA, et al. Innovative technologies of nursing care. Rev Enferm UFSM. 2012; 2(1):182-9. doi: http:// dx.doi.org/10.5902/217976923591 